\title{
Notes on Gametophyte and Young Sporophyte of Angiopteris suboppositifolia de Vries*
}

\author{
by Yoshitomo NozU**
}

野津良知**：リュシビンタイの配偶体と若い造胞体についで

Received June 30, 1956

Recently, in order to solve various problems of the morphology and phylogeny of ferns, important studies on the nature of gametophytes and young sporophytes are rapidly increased and studies on the gametophyte of the Marattiaceae have been given by such authors as Jonkman (1878, Marattia and Angiopteris), Farmer (1892, Angiopteris evecta), Campbell (1911, Marattia, Angiopteris and Kaulfussia), Land (1923, A. evecta), Sasaki (1928, Archangiopteris Somai), Haupt (1940, A. evecta), and Stokey (1942, Marattia samỏucina).

In December 1955, the writer had an opportunity to collect a considerable number of prothallia and a large amount of fully matured spores of Angiopteris suboppositifolia de Vries at Yawatano, Izu Peninsula, Shizuoka Prefecture. Most of the prothallia collected there bear young sporophytes showing various stages of their development and some of them are provided with sexual organs. The spores were sown on Sphagnum in the greenhouse and fortunately they germinated.

The present study on the gametophyte and young sporophyte was made on the basis of the materials collected in nature as well as those obtained in culture. The development of the sexual organs was investigated from the materials embedded in paraffin after fixation with formalin-acetic-alcohol and sectioned by microtome.

\section{Observation}

In this species radial spores are predominate. They measure $40 \times 50$ microns in average size. In culture they usually germinate within two weeks and germination occurs in a split of spors coat. Chloroplasts may be seen in the first cell of gametophyte. When 1-2 cells are formed a rhizoid emerges from the ventral surface of the basal cell, and it is typically large unicellular and reddish brown or sometimes chocolate brown in colour from its very first appearance. When the filament becomes about 2-3 cells long, a longitudinal division begins in the cell just behind the terminal

\footnotetext{
* Contributions from the Division of Plant Morphology, Botanical Institute, Faculty of Science, University of Tokyo. N.S. No. 74 .

** Botanical Institute, Faculty of Science, University of Tokyo 面京大学理学部植物学教室
} 
cell (Fig. 3), though occasionally there is no filament stage but such a division takes its place in all cells immediately after the germination. The thallus increases gradually its width by subsequent longitudinal and transverse divisions (Figs. 4, 5). At the time when the thallus grows nearly to the stage shown in Fig. 5, an apical cell may be found usually at a more or less lateral position of the thallus. The apical cell undergoes frequent divisions to form a cordate thallus preceeding to its activity is replaced by marginal meristems, though, under some unfavourable conditions, a spatulate thallus is occasionally formed (Fig. 6). The further growth of the thallus is, however, approximately symmetrical, though an unusual activity of the marginal initials occasionally

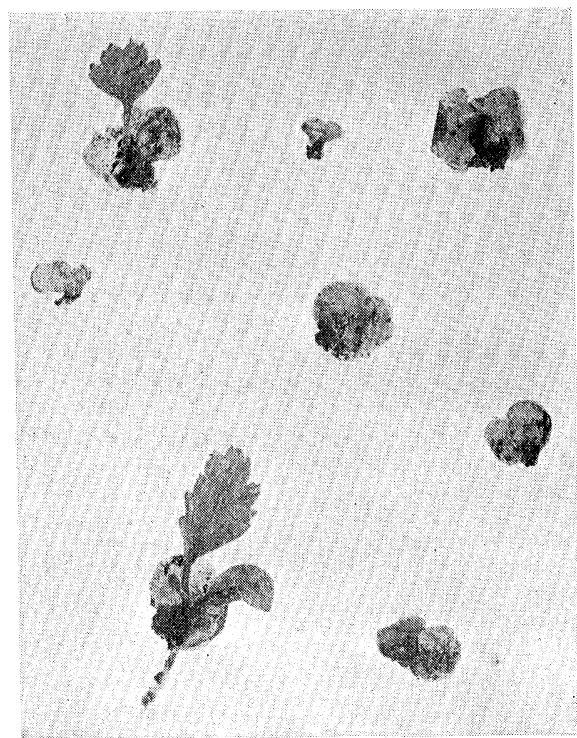

Fig. 1. Young sporophytes of Angiopteris suboppositifolia attached to the gametophytes. $\times 1.5$.

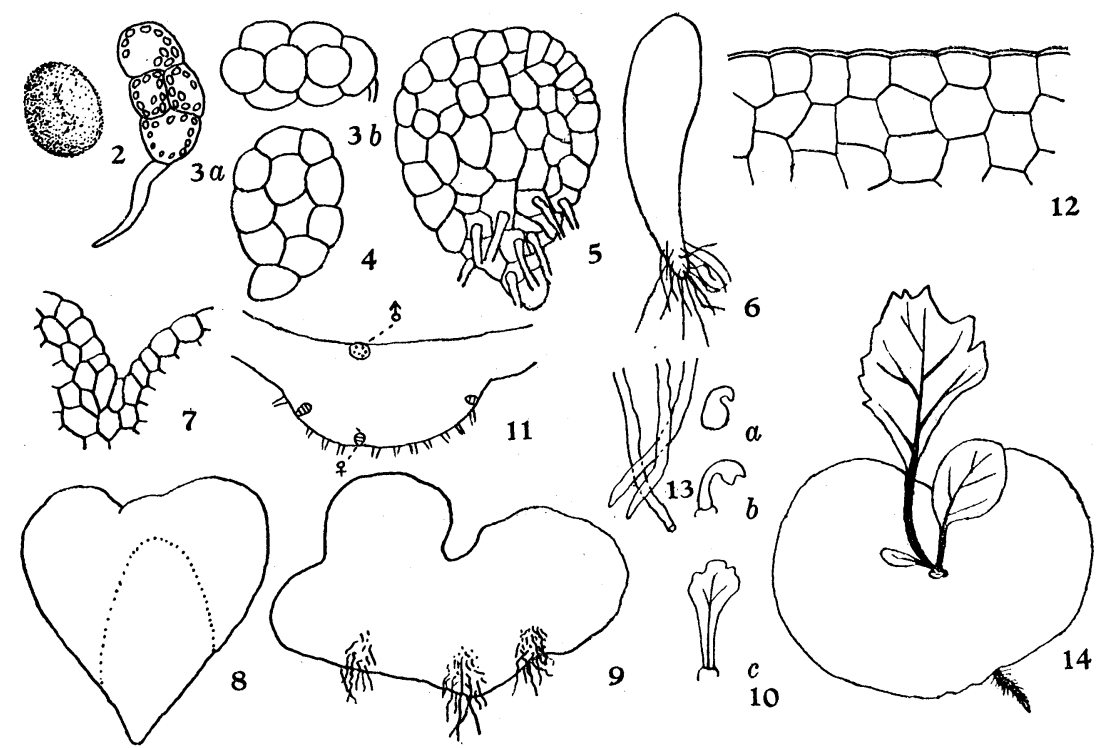

Fig. 2. Spore. Fig. 3. a, Beginning of germination (normal type). b, Massive one (abnormal type). $\times 150$. Figs. 4, 5. Development of gametophyte showing an apical cell. Fig. 6. A case of spatulate form. Fig. 7. Detail of apical part of a young gametophyte. Figs. 8, 9. Asymmetrical gametophytes. Fig. 10. a, b, c. Juvenile leaves. Fig. 11. Cross section of the gametophyte showing the position of sexual organs. Fig. 12. Marginal portion of gametophyte. Fig. 13. Apices of rhizoids. $\times 150$. Fig. 14. Juvenile leaves attached to the gametophyte. 


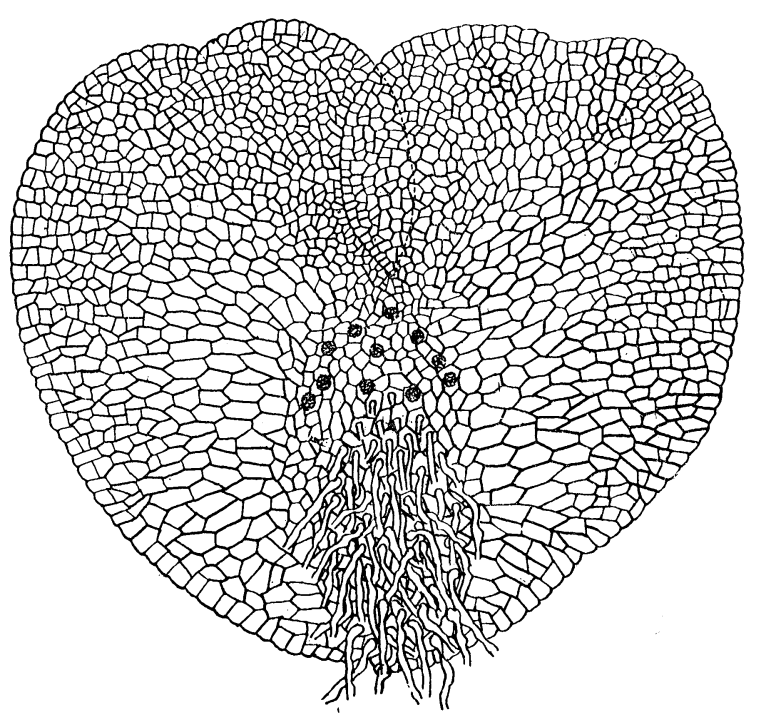

Fig. 15. Detail of a mature gametophyte (ventral view).

results an asymmetrical form (Figs. 8, 9). In mature state (Fig. 15) the thallus assumes, alike the usual type of Polypodiaceous ferns, a broadly cordate form which is characterized with a deep notch and well developed wings composed of thin-walled cells containing numerous chloroplasts. The wing is of one cell in layer excepting the portion which is adjacent to the midrib (Figs. 11, 18). The fully grown prothallia bearing sex organs measure mostly from 5 to $10 \mathrm{~mm}$ both in length and in width (Fig. 15). But in the

case of the older ones the wings are ruffling. Large numbers of unicellular rhizoids (Fig. 13) are found excepting the marginal portion. The marginal cells have no hairs (Fig. 15).

The midrib is about 10 cells thick and projected markedly on the ventral surface. Branching of the midrib is found on some asymmetrical gametophytes (Fig. 9). The gametophyte occasionally persists until the third leaf is fully matured. In culture, if conditions are favourable, a massive thickening of the thallus may occasionally occur at an early stage (Fig. 3, b). In this stage, a thallus is composed of about eight cells with chloroplasts.

Antheridium - Antheridium of the present species shows many particularities in its habit, form, as well as in its development. The antheridia occur usually on the dorsal side, rarely also on the ventral. The antheridium initial originates from the superficial cells of the thallus. It can occasionally be distinguished from the other superficial cells by its larger nucleus. The initial divides into the outer cell and inner cell by a periclinal wall. The outer of the two cells divides anticlinally, while the inner cell gives rise ultimately to the spermatogenous tissue. The two resulting outer cells then divide slightly oblique or anticlinally, namely, the primary cover cell undergoes three anticlinal divisions forming in the center a triangular opercular cell which is located at the more outer portion of the antheridia (Fig. 16). The inner cell is divided firstly by an anticlinal wall and subsequent divisions of these cells are simultaneous. The spermatocyte mass is cut off from the surrounding cells by a mantle or jacket layer, but it is sometimes incomplete (Fig. 17). At the later stage, the coiled spermatozoids are clearly visible in section. An antheridum may contain 30 to 60 sperms. Thus, the antheridium assumes a form of 
sunken and large ball, there being a great range in their size. Broken opercular cells are observed elsewhere, though the behaviour on the dehiscence of the antheridium was not observed.

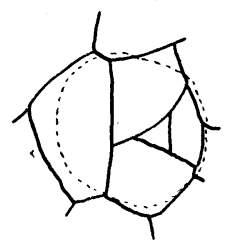

Fig. 16. Surface views of an antheridium and triangular cap cell. $\times 600$.
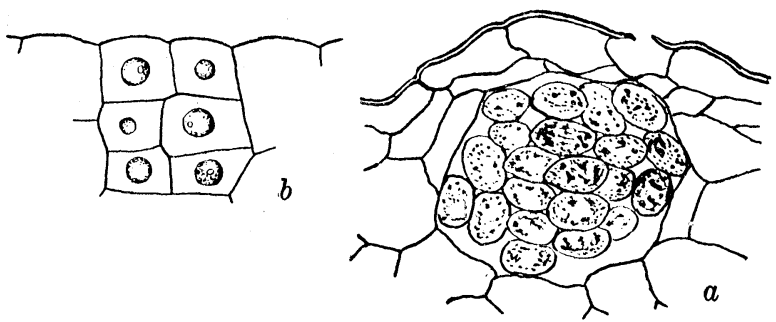

Fig. 17. a, Longitudinal section of a mature antheridium. $\times 600$. b, young antherium. $\times 600$.

Archegonium-The archegonium is always produced on the ventral side of the prothallium when it is about one month old in culture. They appear in considerable numbers, but rather less than in most of the Leptosporangiate ferns. The initial cell may be distinguished from the neighbouring superficial cells by its larger nucleus and the deeply stained cytoplasm. The development of archegonium proceeds in the usual manner, as given by Haupt (1940). Namely, the initial is divided into primary neck cell and the central cell by a periclinal wall. The primary neck cell soon divides into two, then four by successive anticlinal divisions. Differing from the case of many ferns, neck of the archegonium does not project prominently from the surface, but bulges out a little above the surface. In the meantime the central cell divides into two, a ventral cell and a neck canal cell, one of which, that is, the ventral cell, soon divides in the usual fashion again into a ventral canal cell and an egg. The ventral canal cell relatively large, while the egg is rather small and lies at the bottom of

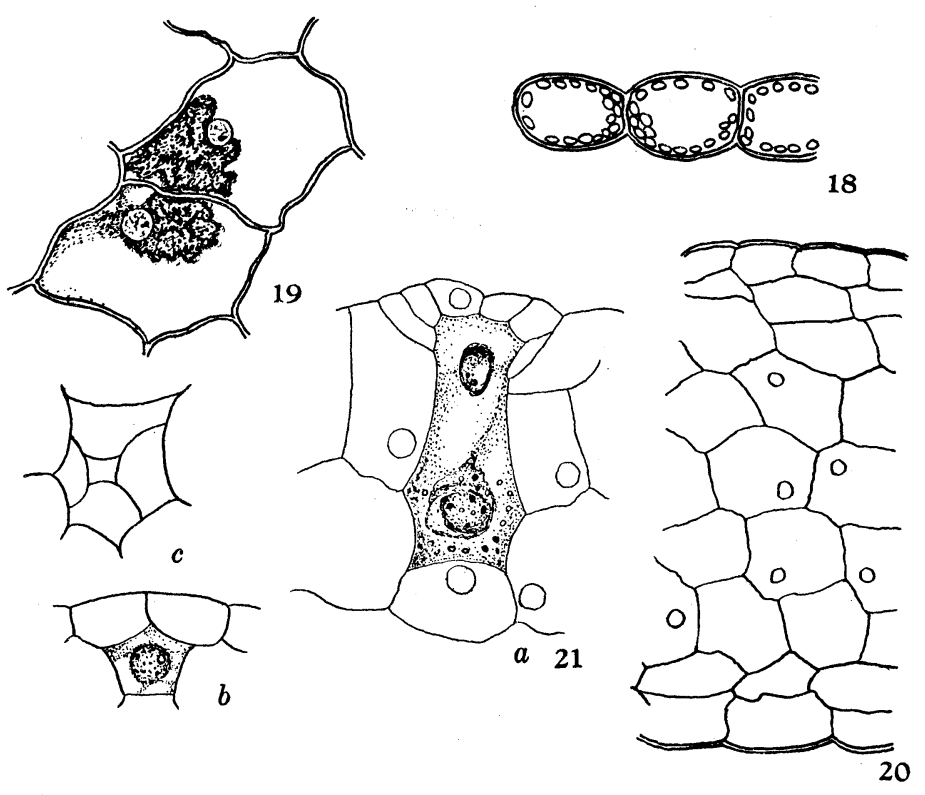

Fig. 18. Cross section of marginal portion of the gametophyte. $\times 150$. Fig. 19. Cells of midrib. $\times 600$. Fig. 20 . Cross section of a part of midrib. $\times 600$. Fig. 21. Archegonium. a, Mature archegonium in longitudinal section. $\times 600$. b, Young archegonium in longitudinal section. $\times 600$. c, Surface view. $\times 150$. 
the wide archegonial cavity. The neck canal cell is broad and divided into two, but usually the division wall may be found. The basal cell is not always found.

Young sporophyte-Earlier stages of the leaf development are shown in Fig. 10. At the one end of the embryo the divisions are more active and gradually the initiation of the stem and the primary leaf can be recognized. At a comparatively later stage the endogenous structure of the primary root makes its appearance by

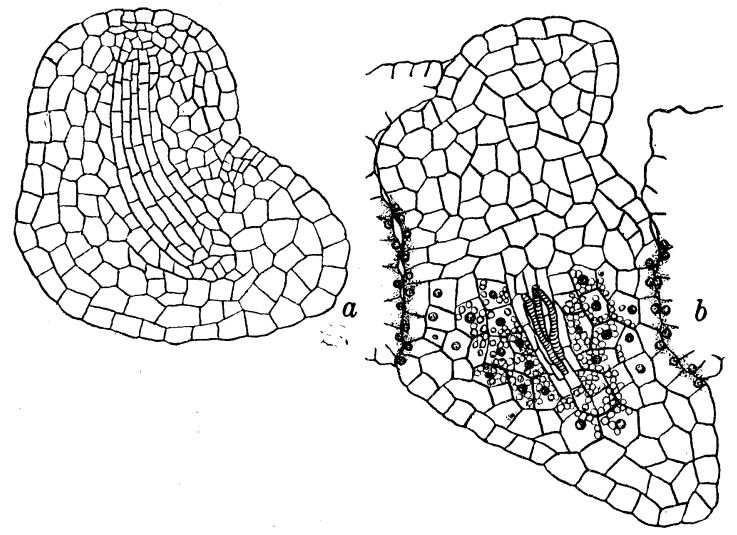

Fig. 22. Longitudinal sections of embryos in advanced stage. $\times 150$. the active cell divisions in the another end of the emdryo, and the root soon emerges on the lower side. The apical cell of the root is essentially tetrahedral, though in the later stages this condition is apt to be obscure. The derivatives of the apical cell appear by anticlinal divisions. The cortex is derived from the middle and to some extents from the inner and outer cells which resulted

:from the periclinal divisions of

the cells adjacent to the apical cell. In the primary root can usually be found a centrally placed vascular bundle which is provided with two or three spiral tracheids. At this stage, tannin can be recognized in most cells of the cortex which are stained very strongly with safranin, starch grains being also found at the inner region of the cortex.

A primary leaf appears on the dorsal surface as a small protuberance as is shown in Fig. 10, a. A primary leaf may reach the length of $10 \mathrm{~mm}$, and the lamina usually acquires the shape of a fan (Fig. 14), though the form is variable as reported by Campbell (1911). The venation of successive juvenile leaves changes from dichotomous to sympodial branching.

\section{Discussion}

There are notable differences between the morphological characters of the gametophyte of Angiopteris and those of the Polypodiaceous ferns. Those which are of special interest are:
a) particular feature in the form of
c) markedly thickened midrib
the thallus in the early stage of
d) absence of hairs
its development
b) characteristic dark green colour of the thallus rhizoid
f) sunken and large antheridium
e) reddish brown, unicellular and large 
g) archegonium with less projected neck cells h) small egg and wide archegonial cavity

After the germination of spore, the filament does not markedly elongate as in the case of many other ferns, but the short filament is soon transformed into a thin and more or less broad body, or, occasionally in culture, into somewhat massive one. It is interesting enough in this connection that these two conditions agree respectively with the "plate" and "mass" formation pointed by Stokey in an earlier stage of the prothallium development of such primitive ferns as Marattia, Dipteris and Matonia (1942, 1945, 1952). One of the characteristics of the genus, the strikingly deep green colour of the prothallia is said to be related to their long-lived habits as pointed out by Eames (1936) and Haupt (1953). The midrib of the prothallia in Angiopteris may reach about 10 cells in thickness. It also agrees with the case of primitive ferns such as Matonia, Dipteris, Gleichenia and Cheiropleuria. As Land (1923) pointed out, the markedly thickened midrib of Angiopteris, as well as of the other primitive ferns mentioned above may be capable as a feature which indicates a certain relationship with such ferns as Psilotaceae, Lycopodiaceae and Ophioglossaceae whose gametophytes are massive and subterranean in their habits. Furthermore, the absence of hairs excepting unicellular and large rhizoids in the gametophyte of this genus seems to be received as a characteristic of the primitive ferns.

The character of sex organs of Angiopteris is not found in any other ferns, excepting relatively few lower members. The antheridium in Angiopteris is of the sunken type with divided cap cells and the spermatocyte mass which produces 30 60 sperms. The development of the antheridium in Angiopteris resembles that of other members of the Marattiaceae and Ophioglossaceae (Campbell 1911, Haupt 1940 and Nozu 1954). Also a triangular opercular cell in the antheridium is a characteristic known only in a few of other ferns. So far as the writer's observation is concerned, a large numbers of archegonia are born only on the ventral surface, though Jonkman (1878) found them also on the dorsal side. The archegonium of this species is short and scarcely projects above the surface. So far as they are known, such a type of archegonium (also antheridium) is known only in some Eusporangiate ferns. In Archangiopteris, Sasaki (1928) found that the archegonia were situated near its median portion of the ventral surface of the thallus and took a small circular form. Ophioglossaceous ferns are example of such a case, but the archegonium neck of them is more slightly projected than in the case of Angiopteris. As Jonkman and Farmer illustrate, an archegonium is always project provided with a canal composed of two conspicuous neck canal cells, there being never observed a single binucleate neck canal cell which was found by Campbell (1911) in Marattia. The egg is small and lies at the bottom of the wide archegonial cavity, as pointed out by Haupt (1940) and Stokey (1942). In Angiopteris a basal cell in the archegonium does not always be found, as was reported by Farmer (1892) and Haupt (1940). 
Though it is unnecessary to discuss an early development of the young sporophyte here, because Farmer (1892) and Campbell (1911) already reported in detail, it is to be noted that the tannin cells adjacent to the vascular bundle are conspicuous and the definite endodermis is not found.

As already mentioned above, most of characteristics of the gametophyte in $A \boldsymbol{n}$ giopteris are indeed primitive and show little affinity to other ferns. In regard to the question of the relationship of the Marattiaceae to Ophioglossaceae, Campbell (1911) states that they show a marked resemblance in many respects. However, in the writer's observation the gametophytes of both Angiopteris and Ophioglossaceae resemble each other in its antheridial characters but differ both in mature features and in archegonial characters, just as in the case of sporophyte.

\section{Summary}

The gametophyte and young sporophyte of Angiopteris suboppositifolia grown in nature and in culture were studied. Spores germinated about two weeks after, giving rise to a very short filament which develops soon to form a thin body or, rarely in culture, somewhat massive one. The fully mature thallus is characteristic dark green in colour and broadly cordate with a midrib which may reach about 10 cells in thickness. Excepting unicellular, large and reddish brown rhizoids, no hairs are present at any stage. Antheridium is situated on the dorsal surfaces, rarely also on the ventral; they are of the sunken and large primitive type with a triangular cap cell and a large output. Archegonium is situated always on the ventral surface; the archegonium neck is short and scarcely projects above the surface, and the small egg lies at the bottom of the wide archegonial cavity. In the type of germination and in the form of mature thallus, Angiopteris shows the primitive type of the Leptosporangiate ferns, while in the features of sex organs it resembles closely such Eusporangiate ferns as the other genera of the Marattiaceae and Ophioglossaceae.

The writer wishes to express his heartfelt thanks to Em. Prof. Y. Ogura and Assistant Prof. S. Watari, University of Tokyo, for their kind advices and many courtesies.

\section{Literature Cited}

Campbell, D. H., The Eusporangiate. Carnegie Institution of Washington, Publ. 140. (1911). Eames, A. J., Marattiaceae. Morphology of vascular plants. 144-156. N.Y. (1936). Farmer, J. B., Ann. of Bot. 6: 265-270. (1892). Haupt, A. W., Bull. Torr. Bot. Club. 67: 125-129. (1940). , Marattiales. Plant Morphology. 464. (1953). Jonkman, H. F., Bot. Zeitung 36 : 129-136, 145-153. (1878). Land, W. J. G., Bot. Gaz. 75: 421-425. (1923). Nozu, Y., Phytomorphology 4 : 430-434. (1954). Sasaki, S., Bot. Mag. Tokyo 42: 233-236. (1928). Stokey, A. G., Bot. Gaz. 103: 559-569. (1942). — Bot. Gaz. 106: 402-412. (1945). —_ Phytomorphology 2: 138-150. (1952). 